ARTICLE

DOI: $10.1057 /$ s41599-017-0038-8

OPEN

\title{
East Asian Gothic: a definition
}

\author{
Colette Balmain ${ }^{1}$
}

ABSTRACT This paper offers a definition of East Asian Gothic cinema in which a shared cultural mythology, based upon cultural proximity and intra-regional homologies, provides a cinematic template of ghosts and ghouls together with a grotesque menagerie of shapeshifting animals, imagined as either deities or demons. East Asian Gothic is an umbrella term which encompasses the cinemas of PRC, Hong Kong, Taiwan, Japan and South Korea, acknowledging the difficult histories and conflicts between the nations, as well as film making practices and industries. This is in opposition to critical work which views East Asian gothic and horror films as extensions of Japanese horror, and therefore J-Horror as a meta-genre; for example David Kalat in J-Horror (2007) and Axelle Carolyn in It Lives Again! Horror Films in the New Millennium (2008), or focus almost solely on the relationship between contemporary Western and East Asian Horror cinema through an analysis of the remake. In order to demonstrate the transnational and regional flows that form East Asian gothic cinema, this paper focuses in on one of the oldest and most enduring gothic figures found in literature and mythology across East Asia, the nine-tailed fox: known as the huli jin in China, gumiho in Korea and kitsune in Japan. While much has been written about the vengeful ghost, little attention has been paid to that of the fox-spirit even though 'she' is ubiquitous in East Asian popular culture. On screen, the fox-spirit (also known as the fox fairy) is either represented as a variation of the femme fatale or the sacrificial woman-or indeed both in some casescreating a parallel between existing gender relation and the gothic imaginary. This paper explores the representation of the fox-spirit in contemporary Chinese cinema, at two ends of the spectrum in terms of budget and ambition, the big budget, CGI spectacular, Painted Skin (Hua Pi; dir. Gordon Chan, China/Hong Kong/Singapore, 2008) and the low-budget, low fi, The Extreme Fox (dir. Wellson Chin, Hong Kong, 2014) in order to map out the multiple border crossings which are constitutive of East Asian Gothic: while Painted Skin is representative of a global, or globalising trend, in East Asian Gothic Cinema, The Extreme Fox can be understood as resistant to globalisation through the emphasis on the local and the regional.

\footnotetext{
${ }^{1}$ Kingston University, Thames, UK. Correspondence and requests for materials should be addressed to C.B. (email: C.Balmain@kingston.ac.uk)
} 


\section{Introduction: East Asian Gothic}

$\mathrm{n}$ his seminal study, Botting locates the Gothic as the monstrous, repressed past of Enlightenment rationality. He writes "Aesthetically excessive, Gothic productions were considered unnatural in their under-mining of physical laws with marvellous beings and fantastic beings" (1995, p 4). In a similar manner, Punter argues that paranoia, the barbaric and taboo are "the aspects to which Gothic constantly, and hauntedly, returns" (1995, p 184). The Gothic is almost always understood as a specifically Western form which emerges as the underside of the Enlightenment. For example, Hogle in his introduction to The Cambridge Companion to Gothic Literature contends that "the Gothic is a form of Western fiction-making" (2002, p 7) while Baldick argues that the Gothic is "neither immemorial or global, but belongs specifically to the modern age of Europe and the Americas since the end of the eighteenth century" (1993, p 20). Fowler points out that while the Gothic began as a "fixed genre", it soon "yielded a gothic mode that outlasted it" (1982, p 109).

Existing work on East Asian literature and cinema has utilised the Gothic as either a translation term, mode or as a meta-theory, acknowledging that the Gothic is a concept which is historically and culturally specific to the West. The most extensive analysis to date is that of Hughes in 'Familiarity of the Strange: Japan's Gothic Tradition' (2000). He argues for the Gothic as "a translation term for a similar tradition observable in both cultures" (2000, p 84). In these terms, East Asian Gothic cannot be reduced to a copy of an original-something which is imported into East Asia during the colonial period-but rather is an indigenous genre with similar themes and concerns to that of the Western Gothic: "one immediately sees East-West similarities in the psychosexual matrix through which the Gothic expresses the struggles of the spirit and the flesh" (Hughes, 2000, p 67). In a similar manner to Fowler, Nakagawa in her insightful analysis of Village of Eight Gravestones (Yatsuhaka-mura; dir. Yoshitarō Nomura, Japan, 1977), defines the Gothic "as a mode of writing that refers to the past in negotiation with the present and/or that which emerges out of the changing social structure in the modern era" (2013, p 32). In his introduction to Asian Gothic, Andrew Hock Soon Ng suggests that the Gothic has not only superseded its generic origins but that it has become "a theory in its own right, requiring particular methods and vocabulary to discuss the way in which texts may be read and appreciated" (2008, p 1).

What is agreed on in relation to the East Asian Gothic is that the "Gothic" cannot be used in a simplistic manner: as Stein and Browning point out in their analysis of the vampire in Japanese Gothic, East Asian Gothic is a "complex multiplicity ... of merging and interrelated cultural, political, and social resonances... [which] has to do with an intermixing of Taoism (animism and nature), Confucianism (politics, the ethical and the social) and Buddhism (spiritual and psychological)" (2008, p 211). Lim also stresses this when discussing the fantastic in South East and East Asian cinema. She writes that "the supernatural and the natural [are] not oppositions but... [rather] co-constitutive' (2009, p 108).

It is essential to acknowledge the difference between East Asian Gothic as a regional category, and the local gothics that constitute it even though they may have a similar point of origin. Hughes contends that "Chinese tales and stories are ... important sources for East Asian Gothic" (2000, p 65). These tales are known as records of the strange (zhiguai) and stories of the marvellous (chuanqi), which are subgenres of the classical tale (wenyan xiaoshuro), the oldest Chinese narrative form. Such stories deal with a fantastic and marvellous world which runs "counter to the rationality, morality, chronology, and temporality of official historiography" (Lu, 2007, p 27). This is line with Lim's argument that "enchantment is an idiom of profound disaffection, a lived and felt register of resistance to the contradictions of millennial capitalism" (2009, p 135). As this paper will argue, the fox-spirit articulates not only the interpenetration of the past and the present in East Asia but also as a liminal creature resists the rationality of official historiography in China in literature and cinema.

While much has been written about the "Asian" ghost especially post Nakata's Ring (Japan, 1998) and Verbenski's subsequent remake, The Ring (2001), little attention has been paid to that of the fox-spirit even though 'she' is ubiquitous in East Asian popular culture and markedly prevalent in contemporary Chinese cinemas. In her analysis of the function of the fox in Chinese literature, Huntingdon writes that to "speak of the supernatural in China is, in one common phrase ... to talk of ghosts and speak of foxes". Indeed, as she goes on to point out in certain periods foxes were almost as common as ghosts in the Chinese literary imagination (2003, p 2). Fox-spirits are liminal creatures that traverse a path between the dead and the living and gods (transcendent beings) and demons (monsters). As such, they are paradigmatic gothic creatures in their liminality. In one of the earliest accounts of the fox-spirit, Jottings from a Thatch House of Close Observations (Yuewei caotang biji, 1793), Yi Lun foregrounds the inherent liminality of the fox:

Human and things are different species, and foxes lie in between things; darkness and lightness take different paths, and foxes lie between darkness and lightness, divine transcendents and demons follow different, pathways, and foxes lie in between divine transcendents and demons ( $\mathrm{Yi}$ Lun cited in Kang, 2006, p 2)

Liminality, according to Williams, lies at the very heart of the gothic. She writes: "Gothic is so pervasively organised around anxieties about boundaries (and boundary transgression) that the border between self and other might indeed characterise the 'essential situation"' (1995, p 16). While in fiction, the fox-spirit can be either female or male, or indeed not properly gendered on screen, the fox-spirit is almost always represented as female, either as a variation of the femme fatale or the sacrificial woman, or in many cases both. In these terms, the fox-spirit draws our attention to the relationship between gender relations and the gothic imaginary.

After mapping out the geographical and theoretical space of East Asian Cinema, this paper begins by investigating the origins of the fox across East Asia in classical tales, folkways and mythology, paying attention to the similarities and differences between the conceptualisation of the hui jing (China), kitsune (Japan) and gumiho (Korea). Following this, the paper investigates two such contemporary cinematic imaginings in Chinese cinema at two ends of the spectrum in terms of budget and ambition, the big budget, CGI spectacular, Painted Skin (dir. Gordon Chan, 2008) and the low-budget, low fi, The Extreme Fox Painted Skin (dir. Gordon Chan, 2008) and the low-budget, low fi, The Extreme Fox. While the first film draws on the codings and conventions of the 'god and demons' genre of early Chinese cinema, the second has more in common with Hong Kong exploitation cinema of the 1970s and 1980s. The paper concludes by exploring the function that cultural proximity (Straubhaar 1991) plays in the construction of the fox narrative in local and regional media forms. Such an exploration of the fox spirit, as gothic creature par excellence, provides a mechanism through which to define East Asian Gothic which takes into account intraregional flows rather than seeing it merely as an Asian version of the Western Gothic. 


\section{East Asian cinemas}

The construction of 'East Asia' like that of 'Asia' is one which is not unproblematic. In 'What does Asia mean', Sun Ge points out that: "Asia is not only a political concept, but also a cultural concept; it is not only a geographical location, but also a measure of value judgement" (2015, p 9). Due to the pervasiveness of discourses of orientalism, "Asia" is often used in binary opposition to the West through a comparative analysis which is shaped by knowledge and power (Said, 2003). Sun Ge stresses that a discussion of "Asia" needs to focus on intra-regional and internal homologies and conflicts, writing that: "the question of Asia must not be merely pursued within the framework defined by the dichotomy of East vs. West, but also should be considered as dealing with internal problems in the Asia regions" (2015, p 10).

This can be clearly seen by a short snapshot of early cinema across East Asia. Unlike in Europe and the US, cinema was not an indigenous art form but rather a colonial import. Cinema was introduced in China on 11 August 1896 by Galen Bocca, a representative for the Lumière Brothers, just one year after its invention. The following year Edison films were brought across from the US by James Ricalton. Films were originally shown in tea-houses, gardens and outdoor tents and typically as part of variety shows or what is known as "chained-sequence-plays" (Zhang, 2004, p 17), where most of the early film production and screenings took place. The first films were based upon popular operas, including Dingjun Mountain, in an attempt to stress the essence of "Chineseness" as a mark of cultural authenticity. Yeh Yueh-yi elucidates "Chinese filmmakers tended to view cinema as a specifically Western invention, yet they also felt compelled to incorporate indigenous forms appropriate for Chinese audiences" (Yeh, 2010, p 78). Films screened up until 1949 offered a cohesive framework of representation influenced by traditional forms - the first indigenous films were single camera shorts featuring extracts from traditional Opera - and sought to construct a national identity that would become over the years increasingly revolutionary and class based reflecting seismic shifts in the political landscape of China. After 1949, Chinese cinema fractured into three separate cinemas: mainland China (PRC), Taiwan and Hong Kong. As Sheldon Hsiao-pen Lu points out "It is difficult to speak of Chinese national cinema after 1949 as a separate entity .... To reduce the history of Taiwan and Hong Kong to that of the Mainland is to suppress their cultural and politically specificity" (1997, p 12). Similarly cinema was imported into both South Korea and Japan in the same year as China. In 1896, the Thomas Edison Kinetoscope was imported into Japan and the first film screened in Kobe on 25th November of the same year. It was almost immediately absorbed into the world of vaudeville (yose) of the misemono show (attracti0n) and thereby under direct control of the yakuza (Standish, 2006, p 36). As in China, film companies looked to the existing theatrical arts for inspiration and performers in particular those from kabuki and shinpa theatrical troupes. In addition, it was necessary to adapt Western techniques and forms in order to localise cinema for the domestic market. Influenced by left wing thinking, early Japanese cinema was concerned with addressing social issues that arose from a rapidly modernising Japan. Unlike the cinematic histories of China, Taiwan, Hong Kong and Japan, the cinematic history of Korea is sketchy as there are few records documenting early cinema and even fewer films: the first film is thought to have been shown in 1903 but there is no more information than that. Seven years later, Korean was annexed by Japan under the Japan-Korea treaty of 1910 and remained under Japanese occupation until the US liberated Korea by focussing Japan to surrender. This was followed by the devastation wrought by the Korean War (1945-1955), during which the US and Russia fought a military and ideological battle for the Korean state: a war which would leave Korean permanently divided between North and South Korea along the DMZ or the 38th parallel. Due to this, "Only fragments remain of Korea's early film history. The vast majority of Korea's early film footage was lost due to neglect or the destruction brought about by the Korean War, and not a single feature produced before 1934 survives in complete form today" (Parquet, 2007).

As a result of the complex history of occupation and colonialism, the flow of cultural products across geographical borders in East Asia is uneven. For example, between 1945 and 1998, Japanese imports into South Korea were banned-although there is evidence that popular culture including manga were smuggled into South Korea, localised and then distributed within legal channels. As a result of this cultural boycott, and tensions within the region, Japan has showed resistance to the dominance of Hallyu (Korean New Wave). This came to a head in 2010 when 6000 people demonstrated against Fuji TV for "airing too many Korean dramas" (Hicap, 2011). Iwabuchi sums up Japan's attitude towards East Asia more generally in the following terms: "Japan's refusal to accept that it shares the same temporality as other Asian nations" (2002, p 159).

As a result, the development of cinema across East Asia was not only determined by the status of film as a colonial import and the need to create a localised and indigenous industry but also a national cinema that was distinctive in terms of other national cinemas in the region. For example, the current focus of the mainland Chinese cinema industry to determine the history and future of Chinese Cinema is first and foremost an ideological battle over the construction of the nation-state through the assimilation of Taiwanese and Hong Kong cinemas. Xie Fei, one of the most prominent Fourth Generation Filmmakers, suggests that we should see Chinese cinema as one rather than three, stating that "we can find an intercommunity of culture, history, language and emotion" (One and Three, 2013). This is encapsulated by the term "cultural China". Huat explicates: "The desire behind the concept of 'cultural China' was not the political displacement of the Communist Party in the now marketized PRC, but more importantly, the possibility of a resurrection of a neoConfucianism that will unite not only the dispersed Chinese population, by extension the larger population of East Asia" (Huat, 2004, p 201). As a result of this, this paper uses East Asian Cinema, and by association, East Asian Gothic Cinema, as an umbrella term which negotiates the power struggle over ideology and history in the region through and functions at the level of the local, regional and global. The films chosen to discuss represent these tensions as Painted Skin circulated both regionally and globally, while The Extreme Fox's market restricted to the local and regional and thus resists the drive towards globalisation and homogeneity of cultural products in the neo-liberal marketplace.

\section{Fantastical foxes}

When a fox is fifty years old, it can transform itself into a woman. When it is one hundred years old, it becomes a beautiful woman or shaman; some become men and have sex with women. They even know events from more than one thousand li away and are good at witchcraft, causing people to be beguiled and lose their senses. When they are a thousand years old, they can commune with the heavens and become heavenly foxes. (Guo Pu cited in Huntingdon, 2003, p 1)

The fox-spirit first appears in Guideways through Mountains and Seas with Supplementary Commentaries (Shan-haijing), a Chinese compendium of ancient beliefs and folkloric creatures 
"mostly compiled from the Warring States period to the Western Han dynasty (c. 4th-c.1st cent. B.C.E.)" (Strassberg, 2003, p 13). The nine-tailed fox - although it can have as little as one tail and as many as a thousand-and has many names: the Chiu-shih or "nine messengers" is the name given to a male fox which has nine joints in its tail, while jiuweihu is that used for a fox which roams the Green Hill Mountains and whose flesh if eaten will protect from insect-poison $(\mathrm{gu})$. In addition, there is a difference between the huli jing (fox essence) and the huxian (fox fairy or fox genie): as a result the fox can be either treacherous or benevolent. The huli jing (huli= fox and jing = life essence) is nearly always used in relation to female foxes and means "the enchantment of a female beauty and her power for lustful destruction", while the huxian is an honorific term used for benign foxes as well as a means to appease baneful foxes (Kang, 2006, p 2). The number of tails signifies their age and status. The older they are, and the more tails they have, the closer they are to heaven and becoming celestial foxes. In some accounts, the fox's trajectory of transformation is from fox to fox-woman, then to nine-tailed fox and finally to immortal fox. The way in which fox spirit achieves wisdom and immortality is through the absorption of energy ( $q i$ or jing) of their sexual partners. The huli jing is associated with negative yin energy as opposed to positive yang energy. In Chinese thought, yin and yang are "complementary and equally important", however as a result of "hierarchal culture and society, yang is consistently priced at the expense of the yin: ghosts are inferior to human beings in the natural and moral order of things, just as daughters are less valuable than sons" (Zeitlin, 2006, p 32). In a similar manner to the female ghost, the fox-spirit seeks sustenance by sucking the life energy out of the male while being careful not to consume too much yang and therefore erode their yin. The life energy or jing of the male is stored in a marble, ball or pill, which can be used for good or evil depending on the circumstances. For example the fox-spirit can sacrifice their accumulation of jing to cure the sick. Chinese belief in fox-spirits is usually attributed to Taoism, with the jing, or life essence, which it absorbs representing the fox's progress "in pursuit of its Daoist goal" (Hammond, 1996. p 373). Hammond argues that literary tales of huli jing represent Qing fantasies and anxieties over the sexual role of women (1996, p 380). Significantly, it is only the gaze of [male] monks and priests that can penetrate the fox's disguise. As Chao points out "Tales of fox spirits are identified as a subgenre of the femme fatale stories common in Chinese literature ... Fox spirits stories may similarly be understood as critiques of powerful or anomalous women and expressions of anxiety at times of political upheaval, foreign incursions, and the blurring of gender boundaries" (Chao, 2013, p 139). This blurring of gender boundaries is signified by the presence of both female and male elements: the tail is associated with the phallus, while the jewel that the fox spirit carries in its mouth represents the womb. As Wieringa writes 'its tail is generally considered to be a phallic symbol, while often a jewel that is either balanced on the tip of its tail or held in its mouth is associated with the womb.'(2007, p 29). Hence, the more tails that a fox-spirit has the more powerful and therefore dangerous it is which explains the ubiquity of the female nine-tailed fox in East Asian gothic cinema.

Most origin stories have the fox originating from China before being exported to Japan and then to Korea. Johnson, however, points out the similarity between indigenous (Ainu) tales of foxspirits and later ones. As such, he suggests that China is not necessarily the original source for Japanese stories of fox-spirits (1974, p 34). To demonstrate this Johnson discusses the Japanese tale of Tamamo-no-Mae in which an evil white fox with nine tales, Hua-yang (the consort of a King called Pao-Tsu), flees from India to China where she marries a powerful King (the King differs depending of the story) bringing down the kingdom as a result of her brutality and greed. Once her true status discovered, she escapes to Japan bringing death and destruction with her. There can be little doubt that Tamamo No Mae in her various incarnations is the archetypical female fox. Her sexuality and avarice, has earned her title of one of the Three Terrible Yōkai of Japan (Nihon San Dai Aku Yōkai). While she doesn't always have nine tails, in one variation she only has two, what accounts agree on is her outward beauty which is enhanced by the radiance surrounding her and her sweet aroma: all of which function to disguise her hideous nature. And although in contemporary culture, the fox is most often depicted as female, Tamamo-noMae is not always female-indeed in one story, the fox is a 42 foot tall male.

The oldest version of Tamamo-no-Mae can be traced back to the 14th century BC. In this extant version when Tamamo-noMae is eventually tracked down and killed, she turns into the death rock of Nasuno resulting in the death of all living creatures in the vicinity (Goff, 1997, p 73). However while the kitsune is most commonly associated with evil and bad fortune, they also may be represented as messengers of Inari, a Shinto protector and Goddess of rice and prosperity. During the creation of Japan, Inari descended from Heaven on a white fox carrying cereal/grain (Opler and Hashima, 1946, p 4). In the 11th century, Inari became associated more with the Fox God and with propensity for evil rather than good (Davis, 1992, p 93). The colour of the fox signifies the fact that the fox is over 1000 years old and has achieved a state of great wisdom (Opler and Hashima, 1946, p 44). While the kitsune is often represented as one of the most terrifying of all Japanese monsters or $y \bar{o} k a i$, there are relatively few cinematic representations. This can be explained by the rationalisation of beliefs in fox spirit and fox possession during the Meiji period through medicalisation and criminalisation: fox possession was reclassified as a mental illness and any attempt by shamans to exorcise such spirits was made punishable by law in 1905. Dismissed as superstition and having no place in modern Japan, yōkai disappeared from the pages of horror and gothic literature until the yōkai boom of the 1980s; however the representation of the yōkai was far removed from their original monstrous origins. Instead of threatening monsters, the yōkai became child-friendly, often appearing as heroes in videogames, television and anime.

Unlike the huli jing and kitsune, Korean foxes or gumiho are less ambiguous as Sung-Ae Lee points out: "In Korean folktales, foxes are predominantly female and almost always evil -female foxes take on human form to seduce or devour unwary men... the Korean term for fox, yeowoo, is also used of a scheming woman..." (2011, p 135). However there is a great deal of similarity between the huli jing and the gumiho. In 'The Jewel of the Fox's Tongue', the gumiho sucks the life out of 99 school boys, just needing one more to attain immortality, using a jewel to contain the boys' energy. She is defeated when her final victim swallows the jewel instead. Lee writes, "the fox's jewel both absorbs human energy and can be a source of wisdom or physical power" (2011, p 137). In the second tale that Lee discusses, 'The Girl-Fox and Her Brother', the gumiho eats its victims' livers rather than absorbs energy from them in order to achieve immortality. In other variations, the gumiho eats the hearts of its victims. However unlike the huli jing and kitsune, the fox in both these stories is depicted as inherently evil. Lee argues that these two stories taken together provide the 'fox-woman script' which influences contemporary representations of the gumiho. In another tale, 'The Nine Tailed Fox', a man who is urinating at the roadside discovers he has been urinating on a white bone. The man asks the bone whether it is hot or cold, to which the bone always replies in affirmative. To escape the bone, he tells it that he 
is going to buy it some wine and flees instead. Years later, he comes across another wine shop which is in front of the one he had used to escape from the bone. When he questions the beautiful young woman in the shop, she transforms into a gumiho, complete with nine tails, and proceeds to eat him (Johnson, 1974, pp 46-47). Johnson concludes from his analysis of fox lore in East Asia that "Korean tales tend to consist basically of evil foxes transforming themselves to human shape and destroying people" (1974, p 45). The gumiho is nearly always female, the only exception to the rule is 'The Maiden who Discovered a Kumiho through a Chinese Poem' in which a male fox tries to deceive a beautiful maiden to marry him.

While foxes are not necessarily evil, and in fact may be harbingers of good fortune, the fox as beautiful but duplicitous woman is the most prevalent in mythology and folktales across East Asia as already discussed. In addition, the receptacle or jewel that the fox-spirit uses to trap its victim's lifeforce can be stolen by the intended victim by absorbing the jing contained in the receptacle or sacrificed for the greater good of the community by the fox-spirit itself. While aspects of fox mythology differs across East Asia, there is a marked similarity between accounts of the huli jing, the kitsune and the gumiho, especially those that focus on the female fox as devious seductress whose purpose is to steal jing in order to complete a transformation from fox to human. As in Japan, the Korean' gumiho is relegated a secondary status viza-viz the archetypical vengeful ghost. Films in which she does appear-which are few and far between - tend to stick closely to the traditional 'fox-woman' script in depicting the gumiho as sexually voracious and inherently dangerous and positioning her in direct opposition to the good woman/wife. As with the kitsune, in contemporary South Korean popular culture the gumiho has been domesticated and is more likely to be found on the small screen and in children's media.

\section{Fox fairies and demons}

While the vengeful ghost has relegated the fox-spirit a secondary status in Japanese and South Korean cinema, in Chinese language cinema the fox-spirit has a much more prominent place. The major source for these films is Pu Songling's Liaozhai Zhiyi (Strange Tales of a Chinese Studio, 2006[1740])—colloquially known in China as Tales of Foxes and Ghosts - which is, according to Derk Bodde, the earliest work in which such stories have a prominent place (1942, p 348). Strange Tales contains 491 short stories, all of which are concerned with encounters with huli jing or ghosts. The protagonist is almost always a failed scholar which mirrors Songling's own status at the time. Most of the stories are told from a third person perspective and either are records of the strange (zhiguai) or tales of the marvellous (chuanqi). The book has become synonymous with the ghost story in China and as a result of censorship restrictions, adaptations for the stage, small and big screen have had to adjust the source material accordingly. For example in 2003, a television adaptation of 'Xie Xiaoqin', Eternity: A Ghost Story, had to be deghostified through the transformation of the female ghost into an immortal in order for the TV series to be shown in mainland China. The fox, or huli jing, does not pose the same type of problems as the ghost and as a result, in most mainland Chinese productions of Stories from a Chinese Studio the the huli jing tends to be the most appropriate substitute. Amongst the films based on Strange Tales are Heng Niang (dir. Shi Dongshan, China, 1931), Liaozhai zhiyi (dir. Huang Tang, Hong Kong, 1960), Erotic Ghost Story (dir. Lam Ngai Kai, Hong Kong, 1990), Ghostly Vixen (dir. Wellson Chin, Hong Kong, 1990), Fox Legend (dir.Wu Ma, Hong Kong, 1990), A Chinese Ghost Story (dir. Wilson Yip, China/Hong Kong, 2011), Painted Skin (dir. Gordon
Chan, China/Hong Kong, 2008), A Chinese Ghost Story (dir Wilson Yip, Singapore/China/Hong Kong, 2011), Fox Fairy (dir. He Keke, China, 2012), The Fox Lover (dir. Niu Chaoyang, China, 2013) and most recently Ghost Story: Bride with a Painted Skin (dir. Mo Sali, China, 2016).

One of the most popular of Songling's tales is 'The Painted Skin' (2006[1760], pp 126-132). In the story, a scholar named Wang comes across a beautiful sixteen year old girl one morning during his daily walk. Immediately taken by her beauty, Wang asks the girl why she is out at such an early hour. She tells him that she was sold as a concubine by her parents and ended up running away from her master because of his wife's jealousy. Feeling sorry for her, Wang takes her into his home and family. She tells him not to let anyone know that she is staying there, not even his wife, Lady Chen. However after a few days Wang relents and tells his wife who advises him to send her away. Nothing happens until Wang comes across a Taoist priest who warns him that he is bewitched. Although Wang refuses at first to believe him, when he arrives home to find he is unable to get into his study where he has been hiding the girl he becomes suspicious. He peers in at his study from a hole in an outside wall and is horrified to see "the most hideous sight, a green-faced monster, a ghoul with great jagged teeth like a saw, leaning over a human pelt, the skin of an entire human body, spread on the bed - on his bed". The monster tears out Wang's heart and runs off with it into the dark night. Ultimately the ghost/monster is defeated by Wang's wife with the help of the Taoist Priest and Wang returns to life (Songling 2006[1740], p 220). There have been a number of cinematic versions of 'The Painted Skin', including Bao Feng's Huapi (1965) and King Hu's 1993 Painted Skin (The Yin Yang Method). There is also a 1979 version which was screened in mainland China: there is some dispute whether this is the 1965 version as Hughes (2000) suggests or a different version but it is impossible to verify who directed the film that was screened. Supposedly it frightened the viewers so much, including an old woman who was scared to death, that it was banned and remains "locked" in the China Film Archive.

Gordon Chan's 2008 version, Painted Skin, is the first mainland China production of Songling's tale and broke Chinese box office records taking over $\$ 14$ million in the first six days of its release. In Chan's film, the green-faced monster is transformed into Xiaowei (Zhou Xun) a thousand year old fox, whose beautiful exterior hides a hideous and demonic interior. The reason for this transformation of the monster/ghost into a fox-spirit as already suggested is most likely due to China's censorship system which prohibits films with any form of supernatural being or theme. As Li Zeng points out in her informative discussion of Painted Skin, "it is no surprise that Gordon Chan changed the ghost character into a fox-spirit and diluted the horror element by emphasising a love triangle" (2009, p 21). Painted Skin sticks fairly closely to the original story with Xiaowei being rescued by General Wang Sheng (Aloys Chen) when she is discovered hiding in a bandit's camp. Despite being a fox-spirit, Xiaowei falls in love with her rescuer and seeks to supplant his wife, Peirong (Vicki Zhao), in Wang's affections. Although her beauty bewitches Wang, he repeatedly refuses to take her as his concubine despite her entreaties. Even when his men start dying mysteriously with their hearts torn out, Wang fails to recognise Xiaowei's true nature. It is Peirong who discovers Xiaowei's secret when she finds her changing out of her human skin. She agrees to sacrifice herself so that her husband and others can live and adopts the outward appearance of the foxspirit to convince her husband that she is the heart-eating demon. When Xiaowei realises that Wang will never be hers even after he kills Peirong, Xiaowei makes the ultimate sacrifice using her stored up life energy to bring the dead, including Wang and Peirong, back to life. 
Throughout the film, the colour design operates as a metalanguage evoking the traditional distinctions between yin and yang, shifting chromatic keys from light to dark, from red to blue, to emphasise the distinction between fox-spirit and human, feminine and masculine principles, warmth and cold, activity and passivity. The mise-en-scène displays the conflict and interaction between yin-(the male principle)—bright, vibrant colours including yellow and red and yang (the female principle) - dark, gloomy and cold colours including blue and blackYellow earthen colours (yang) dominates public spaces and male spaces of activity, while a bluish green colour (yin) dominates private spaces especially those associated with Xiaowei. This contrast is foregrounded in three short scenes in which Wang fantasises of being with the Xiaowei while he is in bed with his wife: all of which are framed through the desiring male gaze. In the first of three, Wang looks down at his wife, only to discover that Xiaowei instead. In the second she is shown walking through the yellow sands of the desert, stopping briefly before turning back to return the camera's and the male gaze. In the final extended sequence we follow Xiaowei as she walks under a tunnel and down into an underground cave. She is dressed in a diaphanous, flowing, red robe. Red is a complex symbolic colour in China in that it is mainly associated with good luck and fortune but is frequently used in literature and film to represent a female revenant or demon. Here it can be interpreted as a visual signifier of Wang's desires. In this scene, Wang finds himself in a maze which leads to the cave and a dank polluted looking lake. As mist swirls around the cave enshrouding the lovers, the camera pans in on Xiaowei's discarded gown moments before she emerges naked from the bottom of the lake. Here the lake represents yin and the discarded robe Wang's desire, or yang, which Xiaowei desires. Discussing the female ghost in Chinese literature, Zeitlin argues that the ghost is 'super yin', "occupy[ing] virtually all points along the symbolic axis of yin (associated with cold, dark, moisture, earth, lower, death, femininity) as defined against the symbolic axis of yang (associated with warmth, light, dryness, heaven, upper, life, masculinity etc)" (2006, p 16). The ghostly atmosphere is pervasive here and evokes [deliberate] visual memories of similar trysts between female ghosts and human men in Hong Kong cinema of the late 1980s and early 1990s, in particular those in A Chinese Ghost Story (Sien nui yau wan, dir. Ching Sui-tung, 1987) and The Bride with White Hair (Bai fa mo nu zhuan, dir. Ronny Yu, 1993). In Chinese folklore, ghosts and fox-spirits are interchangeable with no clear demarcation between them. Both are female, both are seen as threatening of the male's jing or lifeforce, and both seek to replenish their own essence through absorption of the other's. Huntingdon writes "both foxes and ghosts were considered the cause of a particular kind of illness: through sexual intercourse they would drain men's yang essence and endanger their lives" (2003, p 74).

In Wang's fantasies, the cross-cutting between Wang and Peirong in reality and Wang and her monstrous double Xiaowei in fantasy, foregrounds the centrality of the gothic doppelganger, constructing a binary relationship between the two women located at the nexus of male desire and Confucian values and propriety. Unlike in Western gothic where the doppelganger is most often represented as male, in East Asian tales of ghosts and fox-spirits, the double is frequently imagined as female. The double distorts reality, luring Wang in through its deceptive images of female beauty. As Zeitlin points out in relation to classical Chinese literature "the superlative beauty in a woman represents a rupture in the natural order and is almost inevitably interpreted as a mark of otherworldly status" (2006, p 24). In Halberstam's words on gothic monstrosity "The monster is always a master of disguise" (1995, p 95). In Painted Skin, the dead skin is "an old metaphor for disguises and illusions"
(Hughes, 2000, p 65). Skin deceives, disguising the monstrosity that lies beneath its surface. The skin that Xiaowei wears plays on this contrast between surface and depth and appearance and reality. Halberstam argues that skin "represents the monstrosity of surfaces" through which "[d]epth and essence dissolve... and identity and humanity become skin deep" (1995, p 1). Skin, is as Halberstam, points out "the most fragile of boundaries and the most stable of signifiers" (1995, p 163). Appearance is deceptive and failure to look beneath it has deadly consequences. In their introduction to the 1989 translation of Strange Tales, Mair and Mair point out that: "the words "painted skin" have become a synonym for duplicity that wears an outwardly human face but is inwardly demonic"(1989, p 10). When Peirong dons the painted skin, her hair turns white and her skin pale, and she starts to age prematurely. White in Chinese culture signifies "bleakness, starkness, the absence of distinct coloration characteristic of late autumn.... White- 'the colour of metal, of death, of spectres"' (Zeitlin, 2006, p 72). Once again, skin functions to deceive the [male] gaze. According to Do, in this scene, skin represents a symbolic exchange of power between the women. She explicates: "The women gain power through their consumption and through the "painted skin"' (2015, p 185). In contrast, when commenting on the moral dichotomy between Xiaowei and Peirong, Li points out "the demon's dangerous nature and her unregulated female sexuality are enforced through multiple exposures of her sensuous, irresistible, near naked body". Li concludes that like earlier films based upon the stories by $\mathrm{Pu}$ Songling the narrative is shaped by "male discourses on love and gender" (2016, p 119). As such at the end, the fox-spirit's ultimate sacrifice of her carefully stored up jing functions to recuperate her unruly sexuality and reasserts female submission to the dominant male order. For such a transgression, as we discover in Painted Skin: The Resurrection, Xiaowei will be condemned for 500 years in an icy grave. In Botting's discussion of the Gothic, he stresses the "cautionary element of gothic fiction ... depends on loss and recovery", which through doing so it "announces the importance of and at the end, restores, sanctioned values and behaviours" (1995, pp 201-202). Ultimately the huli jing, as is the case of contemporary popular cultural iterations of the kitsune and gumiho, learns to be a good woman through the value and virtue of self-sacrifice.

At the other end of the scale to Painted Skin is The Extreme Fox, a low budget gothic parody. As with Painted Skin, The Extreme Fox is inspired by stories in Strange Tales of a Chinese Studio. Here the protagonist is a Ming dynasty scholar, Wang Seng (Alex Fong), who has failed the Imperial Examinations three times much to the dismay of the Mayor of his hometown who has sponsored his studies and who has been relying on Wang's success to turn around the fortunes of the village. Trying to find a way to turn around his and his village's fortunes, Wang Seng decides to use rumours of attacks by fox-spirits to transform the village into a tourist trap. In the process, he falls for the considerable charms of a fox-spirit, Xian Er (Chrissie Chau). The opening scene draws on typical gothic tropes: a deserted wood at night, swirling mist which makes the landscape difficult to negotiate, and a young woman dressed in white who seems to be fleeing from something or someone. However against type, it is the man who is the prey and woman the predator. The man stumbles and falls. As he does so, there is an insert cut of a closeup of the face of a fox-spirit. While the woman attempts to seduce him, the voiceover tells us "It's said that the evil kitsune are born of the hatefulness and mephitis of the universe. They are immortal. Rejected by the god realm, the hell realm and the human realm, they wanted in the human realm and live by human blood to vent their incessant fury" (Chin, 2014). The scene ends with the fox-spirit sat on top of her prey, holding his heart aloft. So far The Extreme Fox (dir. Wellson Chin, Hong Kong, 
2014) is consistent in its use of generic tropes, setting up the viewer to expect a typical fox-spirit film where which a young man meets a fox-spirit, is entranced by her, becomes romantically and/or sexually involved with her, before the inevitable death of one or the other brings an abrupt end to the relationship. However The Extreme Fox is not a conventional fox-spirit film. It draws on the conventions of Hong Kong exploitation cinema of the 1970s and 1980s, especially the Shaw Brothers films, as much as it does those of the fox-spirit and ghost films. For example, in the next scene we see merchants selling fox-charms and various other fox-expelling machinations and a crowd of people paying homage to the spirit at a makeshift shrine in the market place. This scene is intercut with scenes of so-called fox-spirits as some of the people thronging about talk about kitsune as responsible for the disappearance of children from the village. In addition, subsequent fight scenes are not so much wuxia as derivative of kung fu and martial arts cinema.

This scene discussed above also foregrounds one of the dominant themes in The Extreme Fox which is the commodification of traditional culture in the neo-liberal marketplace. This analogy is extended through the character of Xiao Cui (Tan Li $\mathrm{Nao}$ ), a tour guide - and rival for Wang's affections - who capitalises on the rumours of the kitsune to turn a profit. Wang turns his ancestral home into an inn to accommodate the burgeoning travel industry and as a result brings wealth to Luixian Village, his home town. Zhang discussing the impact of globalisation on China links the commodification of Chinese culture with state ideology and market desire (1998). In a similar manner Yan focuses on the tourism industry and the production of national identity through the marketing of place: "The eventual arrival of mass tourism to China was dependent on the Chinese government's efforts to recast its citizens as modern consumers" (Yan, 2016 p 11). Participating in internal orientalism, The Extreme Fox can be read both as engagement with Chinese supernaturalism and a critique of it: "Chinese supernaturalism appropriates, hybridises, and reconfigures Chinese history, myth, fantasy, and popular culture, especially Chinese cinematic genre traditions, to achieve a transcultural, or "universal" resonance, so as to attain global marketability" (2009, p 159).

While The Extreme Fox is marketed as a variant on the fox-spirit film, the film actually questions the ontological reality of the kitsune through the use of parody. Botting writes "Stock formulas and themes, when too familiar, are eminently susceptible to parody and self-parody" (1995, p 117). Chinese supernaturalism is evident in the manner in which throughout the film the term kitsune is used as an umbrella term for all types of supernatural and demonic foxes. This is demonstrated when Brother Qian comments on the wide breadth of the category kitsune stressing both the positive and negative aspects of fox lore including transcendent foxes who want to be fairies, nine-tailed black foxes and the millennium white. In addition, Wang suffers from narcolepsy which leads to multiple encounters with kitsune, either with a lone fox-spirit or a group of fox-spirits. He always finds himself in the same place, close to an eatery on the edge of the woods which seems to be staffed by kitsune determined to seduce him and steal his jing. When Xian Er takes up residency in his house, Wang is led to believe that she is a fox-spirit. As the filmic events are focalised mainly through the perspective of Wang, the audience is also asked to accept the diegetic existence of fox-spirits.

Along with the embedded references to the strange tales of $\mathrm{Pu}$ Songling, the imagery of the ghostly and the gothic is used throughout the film to evoke traditional iconography of the foxspirit. Swirling mists, dark forests, blue-greenish lighting, unmarked graves and ghost lights, are used as cultural shorthand for the kitsune. However all this is placed under erasure when Xian Er reveals to Wang that she is fact Princess Xianxia and not a fox-spirit. She explains that she ran away from the Palace before her wedding to General Wu Zhen by staging her disappearance as fox abduction, confessing that everything that he saw in the house was in fact staged, using Japanese magic and jiujutsu. This revelation places the very existence of the kitsune under erasure. In addition, through the naming of the fox-spirit as kitsune, The Extreme Fox, collapses the distinctions between the huli jing, gumiho and kitsune. In fact the real demon of the film turns out to be General $\mathrm{Wu}$ Zhen who is seen on two occasions feeding off babies' brains. Yet even though we see this happen, we cannot take this as having actual happening within the diegesis as we are asked to question the validity of what we have seen.

Kavka argues that the Gothic film is a "medium through which things are allowed to pass, from the past into the present, from death to life, from the beyond to hear and back again' (2002, p 236). Gothic film works through the iconography of the visual tied to presence of the otherworldly in a way which sets the viewer's "nerves on edge" (2002, p 236). While The Extreme Fox lacks the sophistication of Painted Skin, the focus on the kitsune and references to Japanese and other East Asian cultures suggest the transmission of culture and cultural meanings across local and regional boundaries. At the same time, they offer distinct epistemological positions related to their locality. While Painted Skin is a variation of the traditional Chinese 'gods and demons' genre (shenmo xiaoshuo), The Extreme Fox has much more in common with Hong Kong exploitation cinema. In addition, Painted Skin uses supernaturalism to try and attract a global market by combined the fox-spirit film with elements of wuxia, while The Extreme Fox explicitly critiques supernaturalism as a form of internal orientalism and self-exoticism through its emphasis on the commodification of popular folklore for the gaze of the Other.

\section{Foxes and borders}

While the shape and form of the fox differs across mainland China, Hong Kong, Japan and South Korea, it is clear that they function within a shared cultural belief system. As discussed in detail, early tales of fox-spirits across the region are markedly similar, especially in the manner in which the fox-spirit becomes a variant of the femme fatale who threatens the male subject with dissolution through absorption of the life force or jing. While it might be difficult to pin down the exact origins of the fox-spirit, and exactly how and when it was transmitted across China, Japan and South Korea, it is clear that the similarities between the huli jing, gumiho and kitsune are not coincidental. Cultural proximity is often used as a way of explaining the existence and transmission of texts across a region. Connected to geo-linguistic and geocultural markets across East Asia, cultural proximity foregrounds the shared characteristics of a region (Iwabuchi, 2002, p 154). In Yang's words, cultural proximity 'posits that culture flows more easily between culturally similar countries than between culturally different ones' (2012, p 109). However, as Iwabuchi points out, cultural proximity does not exist a priori but rather occurs a posteriori through the consumption and reception of media texts (2001, p 56). In Athique's discussion of the formation of geolinguistic markets and cultural proximity across East Asia, he defines East Asia as a geopolitical region composed of "three main geolinguistic regions of varying size: Chinese, Japanese and Korean". This grouping is further subdivided into two antagonistic pairings: China/Taiwan and South Korea/North Korea. This intra-Asian proximity and the corresponding "regional literacy" based around cultural affinity meant that producers are able to capitalise on transnational markets (Athique, 2016). However in an earlier study, Fung argues that cultural homologies are cultural and not "merely generated at production level". Fenge 
contends that "intertextual and cross cultural representation as homologies" play a significant role in the reception of popular culture across national borders (2007, p 272). Significantly, gender stereotypes form one of the most significant cultural homologies: "Overwhelming cultural flows are found in the portrayal of gender qualities" (Fung, 2007, p 274). The portrayal of the good/ bad woman binary in Painted Skin conforms to the existence of Confucian values that underpin patriarchy in East Asia. Even if we equate deviance with transgression, the 'fox-woman script' ends up reaffirming traditional values: Xiaowei is punished for her transgression while Peirong and Wang live happily ever after.

Such intra-Asian homologies can be used to explain the popularity and success of Painted Skin and its sequel Painted Skin: The Resurrection. Painted Skin was released in East Asia by Applause Pictures, which was founded by Peter Chan Ho-sun in 2000 in order to create a unified pan-Asian marketplace: "Applause employs folklore together with ... Asian genre conventions, regional marketing, creative collaborations, and industrial alliances to create multiple trajectories of production, consumption and distribution" (Yeh, 2010, p 92). Painted Skin is notable for being the first Hong Kong/China/Singapore coproduction of a fox-spirit/ghost film. In China alone, Painted Skin broke box office records taking $\$ 14$ million in six days from its opening, while the sequel Painted Skin: The Resurrection set records both in China and Taiwan, taking US $\$ 47.3$ million on 6.65 million admissions over four days in China as well as having the largest opening for a local film in Taiwan. It is now the highest grossing local film of all time taking over $\$ 11.8$ million. 2012 also marked the year that China took over from Japan as the second largest film territory outside of North America. Iwabuchi stresses the fact that "East Asian markets have become increasingly synchronised and producers, directors, actors as well as capital from around the region have been engaged in various creative activities that transcend national borders" (2010, p 199). However the difference between Painted Skin and The Extreme Fox can be read as in terms of the acceptance of globalisation on one hand and local resistance to globalisation or "global localism" (Fung, 2007, p 265) on the other. In Huat's words "No one would ever suggest conceptualising Asia as a culturally homogeneous space. The adjective 'Asian' is complicated by a multitude of possible cultural references, from relatively culturally homogeneous countries in East Asian, such as Japan and Korea to multiethnic/ multiracial/multicultural/multireligious/multilingual postcolonial nations in Southeast and South Asia" (2004, p 200).

\section{Conclusion}

To define East Asian Gothic is to stress the intra-regional homologies between PRC, Hong Kong, Taiwan, Japan and South Korea and the impact of cultural proximity on the circulation of stock gothic figures such as the fox-spirit and the vengeful ghost. At the same time, while the figure of the Asian ghost has proved to be a global phenomenon; the locality of the fox-spirit/fox-fairy arguably has prevented it from doing the same despite the success of Painted Skin and the sequel Painted Skin: The Resurrection. However despite the similarity between the huli jing, gumiho and kitsune, the way in which the fox-spirit is represented in differs significantly from nation to nation. For example, while the eroticism of the fox-spirit is stressed in Hong Kong films, exploration of sexuality in Chinese films is not permitted and as a result, Chinese fox-spirit films centralise romance. In addition, in Hong Kong versions of 'The Painted Skin' which predate Chan's film, the ghost has political connotations along with gendered ones. Luo Hui writes that "The Painted Skin" as a Chinese horror icon is created and preserved in Hong Kong cinema, in great measure, due to Hong Kong's peripheral geopolitical position that allowed the minor discourse of the ghost to continue away from the powerful anti-ghost ideology of Mainland China" (Hui, 2009, p 252). Further in Japanese and South Korean cinema, the kitsune and gumiho respectively have largely been domesticated and shorn of their folkloric origins As such, East Asian Gothic needs to be understood as an umbrella term which encompasses the cinemas of PRC, Hong Kong, Taiwan, Japan and South Korea, acknowledging the difficult histories and conflicts between the nations, as well as film making practices and industries.

A defining feature of East Asian Gothic is a belief in the materiality of the marvellous which is derived from "ancient cultural affinities" (Fung, 2007, p 284) and shared belief systems. In her discussion of 'Asian Gothic', Ancuta writes "With its strong animistic connection, Asia has more than a fair share of its own real literary phantoms to deal with. One significant difference is that in many parts of Asia, spiritual encounters are part of the routine daily existence, since the earthly and spiritual worlds are seen as coexistent" (2013, p 450). For Lim, the co-existence between the real and the marvellous in South East and East Asian cinema articulates "symbolic excess" through which the active force of the supernatural provides a mechanism of critiquing capitalist enhancements" (Lim, 2009, p 135). This takes place through a collapse of the boundaries between fantasy and reality which in Western Gothic are much more clearly defined, with the ghost confined to either the premodern, pre Enlightenment past or the technological post-Enlightenment future.

For example in contemporary China, the term 'fox-spirit' is used to stigmatise women who are believed to have participated in illicit sex or who are seen to be corrupt (Chao, 2013, p 140). In her discussion of the huli jing, Chao points out that the character $h u$ (as in huli jing) at the beginning of a word always has negative connotations, e.g., humei (to bewitch or seduce) and huyi (suspicious, distrustful). Further when used in relation to a woman, $h u$ "pairs her with imagery of sexual immorality, illegitimate power and transgression boundaries" (Chao, 2013, p 140). The continued belief in the fox-spirit is seen to be particularly problematic to the Chinese state. Educational billboards which state that "foxes cannot turn into fox fairies" are erected to try and rationalise the persistence of beliefs in fox spirits (Chao 2013, p 140). While the fox-spirit provides a counter-narrative to that contained within official historiography, its challenge is offset through "the gendering of national time" (McClintock cited in Lim, 2009, p 182) which reinforces social and sexual hierarchies around appropriate femininity. The fox-spirit, as we have seen, supports gendered stereotypes and is represented as a variation of the femme fatale or the sacrificial woman, or indeed both. Xiaowei in Painted Skin is the archetypal femme fatale who is reintegrated into patriarchy through her self-sacrifice. At the same time, even though Xian Er/Princess Xianxia is capable of saving herself in The Extreme Fox, her marriage to Wang at the film's conclusion undermines her deviance and subversion and naturalises sexual inequality and division. As such, there is a clear parallel between existing gender relations and the gothic imaginary in East Asian Gothic cinema. This paper has demonstrated how using Gothic as a translation term enables us to identity a similar tradition observable in both East Asian and Western cultures, without collapsing one into the other.

Received: 15 May 2017 Accepted: 30 October 2017

Published online: 21 November 2017

\section{References}

Athique A (2016) Transnational audiences: Media reception on a global scale. Polity, Croydon 
Ancuta K (2013) Asian Gothic. In: Byron G, Townshend D (eds) The gothic world. Routledge, London, pp 428-441

Baldick C (ed) (1993) The Oxford book of gothic tales. Oxford University Press, Oxford

Bodde D (1942) Some Chinese Tales of the Supernatural. Harvard Journal of Asiatic Studies 6(3-4):338-357

Botting F (1995) Gothic (The New Critical Idiom). Routledge, London

Carolyn A (2008) It lives again!: Horror movies in the new millennium. Telos, Surbiton, Surrey

Chao E (2013) Lijiang stories: Shamans, taxi drivers, and runaway brides in reformera China. University of Washington Press, Washington

Chan K (2009) Remade in Hollywood: The global Chinese presence in transnational cinemas. Hong Kong University Press, Hong Kong

Davis FH (1992) Myths and legends of Japan. Dover, New York

Do MT (2015) Concubines and Chameleons: deconstruction and consumption in $\mathrm{Pu}$ Songling's and Gordon Chan's Painted Skin. In: Gregersdotter K, Höglund J, Hållén N (eds) Animal horror cinema: Genre, history and criticism. Palgrave Macmillan, Basingstoke and New York, pp 168-186

Fowler A (1982) Kinds of literature: an introduction to the theory of genres and modes. Harvard University Press, Cambridge, MA

Fung A (2007) Intra-Asian cultural flow: Cultural homologies in Hong Kong and Japanese television soap operas. Journal of Broadcasting \& Electronic Media 51(2):265-286

Ge SE (2015) What does Asia Mean. In: Chen KH, Chua BH (eds) The Inter-Asia Cultural Studies Reader, Routledge, pp 9-65

Goff J (1997) Foxes in Japanese culture: beautiful or beastly? Japan Quart 44 (2):66-71

Halberstam J (1995) Skin shows: Gothic horror and the technology of monsters. Durham, N.C.; London: Duke University Press

Hammond CE (1996) Vulpine alchemy. T'oung Pao, 82 (Fasc. 4/5):364-380

Heiland D (2008) Gothic and gender: An introduction. Blackwell, Oxford

Hicap, J (2011) Anti-Korean wave tweets cost Japanese actor's career with his agency. Manila Bulletin Publishing Corporation, online publication, 31st July 2011, http://www.mb.com.ph/articles/328745/antikorean-wave-tweets-costjapaneseactor-s-career-with-his-agency Accessed 16 Dec 2015

Hogle JE (2002) The Cambridge companion to Gothic fiction. Cambridge University Press, Cambridge

Hsuan S (2012) Ludicrous Painted Skin. The China Post, online publication, 13th July 2012, http://www.chinapost.com.tw/movie/thriller/2012/07/13/347476/ Ludicrous-Painted.htm Accessed 11 May 2017

Huat CB (2004) Conceptualizing an east Asian popular culture. Inter-Asia Cult Stud 5(2):200-221

Hughes HJ (2000) Familiarity of the strange: Japan's gothictradition. Criticism 42 (1):59-89

Huntingdon R (2003) Alien kind: Foxes and late imperial Chinese narrative, vol 222. Harvard University Asia Center, Cambridge, MA

Iwabuchi K (2001) Becoming "Cultural Proximate": The a/scent of Japanese idol dramas in Taiwan. In: Moeran B (ed) Asian media productions. Routledge, London and New York, pp 54-74

Iwabuchi K (2002) Recentering globalization: popular culture and Japanese transnationalism. Duke University Press, Durham, North Carolina

Iwabuchi K (2010) Globalization, East Asian media cultures and their publics. Asian Journal of Communication 20(2):197-212

Jang J (2012) The Korean Wave (Hallyu) in East Asia: A Comparison of Chinese, Japanese, and Taiwanese Audiences Who Watch Korean TV Dramas. Dev Soc 41(1):103-147

Johnson T (1974) Far eastern Fox Lore. Asian Folklore Stud 33(1):35-68

Kang X (2006) The cult of the fox: Power, gender, and popular religion in late imperial and modern China.. Columbia University Press, Berkeley

Kalat D (2007) J-horror: the definitive guide to the ring, the grudge and beyond. Vertical Inc, Manhattan

Kavka M (2002) Gothic on the screen. In: Hogle JE (ed) The Cambridge companion to gothic fiction. Cambridge University Press, Cambridge, pp 109-228

Krappe A (1944) Far Eastern fox lore. California Folklore Quar 3(2):124-147

Lee SA (2011) Lures and horrors of alterity: adapting Korean tales of Fox spirits. Int Res Children's Literature 4(2):135-150

Li J (2016) The love story, female images and gender politics: Folktale films in thePeople's Republic of China. In: Zipes J, Greenhill P, Magnus-Johnston K (eds) Fairy-tale films beyond Disney: International perspectives. Routledge, London, pp 180-195

Lim BC (2009) Translating Time: Cinema, the Fantastic, and Temporal Critique, Durham, NC: Duke University Press

Lu SH (1997) Chinese cinemas (1896-1996) and transnational film studies. In: Lu HP, Lu SH (eds) Transnational Chinese cinemas: Identity, nationhood, gender. University of Hawaii, Honolulu, pp 1-31
Lu SH (2007) Chinese modernity and global biopolitics: Studies in literature and visual culture. University of Hawaii Press, Hawaii

Lu SH (2012) Notes on four major paradigms in Chinese-language film studies. J Chinese Cinemas 6(1):15-26

Luo H (2009) The ghost of Liaozhai: Pu Songling's Ghostlore and Its history of reception. Doctoral dissertation, University of Toronto, Canada

Mair DC, Mair VH (1989) Introduction. In: Songling P (ed) Strange tales from make-do studio 1760. (trans:Mair DC, Mair VH) Foreign Language Press, Beijing, pp 1-12

Nakagawa C (2013) Desire for the Past: The supernaturalization of Yatsuhakamura. In: Och D, Strayer K (eds) Transnational horror across visual media fragmented bodies. Taylor and Francis, Routledge Research in Cultural and Media Studies, Hoboken, pp 30-39

Ng AHS (ed) (2008) Introduction: The Gothic visage of Asian narratives. In: Ng AHS (ed) Asian gothic: essays on literature, film and anime. Jefferson, North Carolina and London: McFarland \& Co, pp 1-18

One and three: thoughts on a century of Chinese cinema in a century of Chinese cinema (2013) Toronto International Film Festival, TIFF Bell Lightbox, Toronto, Ontario

Opler ME, Hashima RS (1946) The rice goddess and the fox in Japanese religion and folk practice. Am Anthropol 48(1):43-53

Parquet, D (2007) A Short History of Korean Film, Koreanfilm.org, online publication, http://www.koreanfilm.org/history.html Accessed 24 Oct 2017

Punter D (1996) The literature of terror: a history of gothic fictions from 1765 to the present day, 2nd edn. Longman, London

Quéma A (2004) The gothic and the fantastic in the age of digital reproduction. Eng Stud Canada 30(4):81-119

Said E (2003) Orientalism (Penguin classics), London: Penguin

Songling P (2006 [1760]) The Painted Skin. In: Songling, P, Strange tales from a Chinese studio, Minford J (ed) (trans). London: Penguin, pp 126-132

Standish I (2006) A new history of Japanese cinema. Bloomsbury, London

Stein W, Browning JE (2008) The Western Eastern: De-coding hybridity and cyberzen gothic in vampire hunter $D$ (1985) In: Ng AHS (ed) Asian gothic: Essays on literature, film and anime. McFarland \& Co, Jefferson, North Carolina and London, pp 210-223

Strassberg R (2003) Chinese bestiary strange creatures from the guideways through mountains and seas. University of California Press, Berkeley

Straubhaar JD (1991) Beyond media imperialism: Assymetrical interdependence and cultural proximity. Critical Studies in media communication 8(1):39-59

Wieringa SE (2007) Silence, sin, and the system: women's same-sex practices in Japan. In: Wieringa S, Blackwood E, Bhaiya A (eds) Women's sexualities and masculinities in a globalizing Asia. Palgrave-Macmillan, New York and Basingstoke, Hampshire, pp 23-46

Williams A (1995) Art of darkness: a poetics of gothic. University of Chicago Press, California

Xudong Z (1998) Whither China?: Intellectual politics in contemporary China. Duke University Press, Durham, North Carolina

Yan $\mathrm{H}$ (2016) Heritage tourism in China: modernity, identity and sustainability. Channel View, Bristol

Yang J (2012) The Korean wave (Hallyu) in East Asia: A comparison of Chinese, Japanese, and Taiwanese audiences who watch Korean TV dramas. Development and Society 41(1):103-147

Yeh EY-y (2010) The deferral of pan-Asian: A critical appraisal of film marketization in China. In: Curtin M, Shah $\mathrm{H}$ (eds) Reorienting global communication: Indian and Chinese media beyond borders. Urbana: University of Illinois Press, pp 183-200

Zeitlin J (2006) The Phantom Heroine: Ghosts and Gender in Seventeenth-century Chinese Literature. Honolulu, HI, USA: University of Hawaii Press

Zhang Y (2004) Chinese national cinema (National cinemas series). New York: London: Routledge

\section{Data availability}

Data sharing is not applicable to this article as no datasets were generated or analysed during the current study.

\section{Additional information}

Competing interests: The author declares no competing financial interests.

Reprints and permission information is available online at http://www.nature.com/ reprints

Publisher's note: Springer Nature remains neutral with regard to jurisdictional claims in published maps and institutional affiliations. 
(c) (i) Open Access This article is licensed under a Creative Commons Attribution 4.0 International License, which permits use, sharing, adaptation, distribution and reproduction in any medium or format, as long as you give appropriate credit to the original author(s) and the source, provide a link to the Creative Commons license, and indicate if changes were made. The images or other third party material in this article are included in the article's Creative Commons license, unless indicated otherwise in a credit line to the material. If material is not included in the article's Creative Commons license and your intended use is not permitted by statutory regulation or exceeds the permitted use, you will need to obtain permission directly from the copyright holder. To view a copy of this license, visit http://creativecommons.org/ licenses/by/4.0/.

(c) The Author(s) 2017 